\title{
SPATIAL DISTRIBUTION AND SEROPREVALENCE OF NEWCASTLE DISEASE IN KADUNA STATE, NIGERIA
}

\author{
Adanu, W. A. ${ }^{1}$, Umoh, J. U. ${ }^{3}$, Kabir, J. ${ }^{2}$, Kwaga, J. K. P. ${ }^{2}$ \\ Otolorin, G. R. ${ }^{1}$, Olufemi, O. O. ${ }^{1}$ \\ ${ }^{1}$ Department of Veterinary Public Health and Preventive Medicine \\ Faculty of Veterinary Medicine, University of Jos, Bauchi road, PMB 2084, Jos, Plateau State \\ ${ }^{2}$ Department of Veterinary Public Health and Preventive Medicine \\ Faculty of Veterinary Medicine, Ahmadu Bello University Zaria, PMB 1013, Zaria, Kaduna State \\ ${ }^{3}$ Department of Animal Science, Akwa Ibom State University \\ Obio Akpa Campus, PMB 1167, Uyo, Akwa Ibom State \\ Nigeria \\ adanuadanu@gmail.com
}

\section{ABSTRACT}

Newcastle disease is one of the greatest constraints to the development of poultry production in Nigeria. In this study, the spatial distribution of Newcastle disease antibodies was determined using the Geographic Information System. A total of $\mathbf{4 0 0}$ serum samples were collected from chickens in districts around Kaduna Metropolis and screened for Newcastle disease virus antibodies using the haemagglutination inhibition test done according to the procedure of OIE (2002). The spatial distribution demonstrated that the highest antibody titre level for Newcastle disease was closely associated with communities that were at entry points (ZariaKaduna road; Nnamdi Azikiwe bypass road; Television garage; Abuja-Kaduna expressway and Kachia road) to the metropolis and houses that are closely situated near live bird markets signifying the importance of bird movements in the spread of the disease. About $31 \%$ (124 of 400) of chickens had antibodies to Newcastle disease virus, with exotics breeds $(32.0 \%$ ) with more Newcastle disease virus antibodies than local breeds (29.8\%). The Newcastle disease prevalence was $33.9 \%$ ( 39 out of 115 ), $31.8 \%$ (41 out of 129) and $28.2 \%$ (44 out of 156) for Kaduna North, Kaduna South and Chikun Local Government Areas (LGA), respectively. A Newcastle disease prevalence of $29.8 \%$ (54 out of 181 ) was recorded in the local chickens, while $32.0 \%$ (70 out of 219) was obtained from the exotic chickens.

Key words: chickens; entry points; haemagglutination inhibition test; Kaduna; Newcastle disease virus antibodies; Nigeria; spatial distribution 


\section{INTRODUCTION}

Newcastle disease is a highly contagious viral disease caused by an avian paramyxovirus that produces pneumoencephalitis in young chickens, turkeys and other domesticated and wild birds [12]. Newcastle disease is enzootic within individual regions and even villages in Nigeria. Newcastle disease is said to be a major factor affecting the development of the poultry industry in Nigeria and Africa in general [32]. Newcastle disease remains enzootic in states surrounding Kaduna State such as Zamfara and Plateau States, including the Federal Capital Territory [7], with a similarity in climatic and ecologic conditions in these areas. Kaduna metropolis serves as an intersection for the movement between the aforementioned states, as road network plays a major role in the spread of diseases serving as epicentres of disease spread [29]. There have been continuous outbreaks of ND since it was first reported in Nigeria [16]. It has been found to be an epizootic problem in the different parts of Nigeria and continue to cause serious losses in poultry despite vaccination of birds [23]. There has been an emergence of new antigenic lineage of Newcastle disease virus (NDV) in Africa [10].

There have been increasing reports of ND outbreaks in commercial farms in Kaduna metropolis by private veterinarians but the number reported may actually not be representative of the total number of outbreaks due to under-reporting in the current conventional animal disease reporting system and poor veterinary infrastructures [28]. Newcastle disease is particularly devastating for small scale poultry farmers who usually have limited means of protecting their flocks based on the level of their biosecurity practices [32].

Urbanization and increased movement in poultry transportation have resulted in the exposure of chickens to the Newcastle disease virus from infected areas. Since Kaduna Metropolis is an intersection between rural communities and other states due to trade, it could serve as a point of infection for ND in Kaduna State and Nigeria as a whole.

Newcastle disease remains a constant threat to poultry production and has a devastating effect on the productivity of the poultry industry [18]. The current system of disease investigation and reporting is inefficient [11]. There are increasing numbers of ND cases compared to other poultry diseases [4], with a paucity of data about the burden of ND in chickens in Kaduna Metropolis.
Live bird markets contribute to the persistence and spread of ND virus (NDV) [14]. These markets which are found in strategic locations around major road intersections in Kaduna Metropolis usually do not follow appropriate cleaning and disinfecting techniques which allows for the possibility of environmental spread. Live birds are also exposed to birds from multiple sources [29]. These birds run the risk of disseminating Newcastle disease virus as they leave the markets posing a health threat to household chickens [21].

Vaccination has been reported as the only safeguard against endemic ND [2]. In order to formulate appropriate vaccination schedules and control measures, the serological status of NDV among chickens in Kaduna State need to be elucidated. Also, Kaduna State, especially the metropolis, has witnessed massive increase in the demographic population in the last few years and to meet the increased protein demand, poultry and poultry products are being moved to live bird markets across the state for sales [3]. The preference of consumers for this type of meat and the readily available markets justifies the need for this study.

\section{MATERIALS AND METHODS}

\section{Study area}

Our study was carried out in the Kaduna metropolis of Kaduna State. Kaduna Metropolis is accessible via major transportation links from all regions of the country. Kaduna Metropolis lies in three different Local Government Areas (LGAs): Kaduna North, Kaduna South, and Chikun; located between latitude $10^{\circ} 34^{\prime} 57.4^{\prime \prime} \mathrm{N}$ and $10^{\circ} 22^{\prime} 56.6^{\prime \prime} \mathrm{N}$ and longitude $7^{\circ} 38^{\prime} 12.2^{\prime \prime} \mathrm{E}$ and $7^{\circ} 23^{\prime} 29.0^{\prime \prime} \mathrm{E}$. According to the latest census, the city's population in 2006 was $1,128,694$ [24].

\section{Study population}

For serology, the study population consisted of mostly backyard poultry and free-ranging (extensively managed) poultry kept and having the possibility to mix with other birds. Commercial poultry farms were excluded while exotic breeds managed as backyard poultry with local chickens were included.

\section{Study design}

A cross-sectional study was carried out consisting of two separate overlapping descriptive and analytical stud- 
ies on data obtained on spatial distribution and seroprevalence of Newcastle Disease in Kaduna Metropolis from October 2014 to April 2015.

\section{Sampling methods}

\section{Sample frame and sample size determination}

The sampling frame consisted of a list of localities and communities obtained from the Kaduna State chapter of the National Population Commission and local government secretariats that form the Kaduna city area.

Sample size was determined using the formula [33]:

$$
\begin{aligned}
n & =\frac{Z^{2} \times P_{\text {exp }}\left(1-P_{\text {exp }}\right)}{d^{2}} \\
n= & \text { required sample size; } \\
P_{\text {exp }}= & \begin{array}{l}
\text { expected prevalence } \\
\text { (using } 57 \% \text { prevalence }[7]) ;
\end{array} \\
Z= & \begin{array}{l}
\text { standard normal deviation } \\
\text { of } 95 \% \text { confidence level }(1.96) ;
\end{array} \\
\mathrm{d} & =\begin{array}{l}
\text { desired absolute precision }(0.05) .
\end{array}
\end{aligned}
$$

Substituting these values in the formula:

$$
\mathrm{n}=\frac{(1.96)^{2} \times 0.57 \times(1-0.57)}{(0.05)^{2}}=376.63
$$

A total number of 400 chicken blood samples were collected to increase the level of precision.

Kaduna North LGA had the minimum number of districts having 6 districts in total. Six districts each were then selected randomly from the remaining LGAs in the metropolis based on this minimum number, giving a total of 18 districts. A total of 400 chicken blood samples were collected from household poultry farms from the 18 selected districts across the metropolis using convenience sampling. Sampling location was geo-referenced using GIS mapping system to get coordinates.

\section{Sample collection and transportation}

Two millilitres of blood were collected from the chickens through the brachial vein using 21-gauge needles and $5 \mathrm{ml}$ syringes after carefully observing asepsis to avoid any contamination of the blood. The blood was allowed to clot in a cool place to allow the serum to separate from the blood clot. The serum was then decanted into another tube, stored in the refrigerator at $4{ }^{\circ} \mathrm{C}$ and transported to the Viral Zoonoses Laboratory of the Department of Vet- erinary Public Health and Preventive Medicine, Faculty of Veterinary Medicine, ABU Zaria using cooler packs for haemagglutination inhibition tests to detect antibodies to ND virus.

The vaccination status of chickens sampled were not determined during this study in order to get a picture of the level of flock immunity and to control any form of bias towards the protective antibody titre levels to ND virus in the study area.

\section{Sample analyses}

\section{Preparation of chicken red blood cell suspension}

A total of $5 \mathrm{ml}$ of chicken blood was pooled from $3 \mathrm{sep}$ arate apparently healthy chickens aseptically into a disposable syringe containing $1 \mathrm{ml}$ of sodium citrate (4\% solution) as an anticoagulant. The blood was centrifuged at $1,500 \mathrm{rpm}$ for 10 minutes and the plasma and buffy coat were removed with a pipette. After washing three times with phosphate buffered saline (PBS), the $1 \%$ suspension was ascertained to be free of ND antigen or any related antigen capable of cross-reactions. This was done by observing under normal conditions in a U-bottomed microtitre plate and testing for agglutination and agglutination inhibition using ND antigen (La Sota) and ND antibody-positive serum obtained from the National Veterinary Research Institute Vom, respectively, on the same sample.

In the 1 st stage, $25 \mu \mathrm{l}$ of the $1 \%$ RBC suspension was put in a microtitre plate and $25 \mu \mathrm{l}$ of PBS solution was added to it. The plate was tapped gently and kept at room temperature for 30 minutes and observed for settling of the red blood cells. The 2 nd stage was done by adding $25 \mu$ of the ND antigen into a well to which $25 \mu$ of PBS solution was added, followed by $50 \mu \mathrm{l}$ of the $1 \%$ chicken red blood cell suspension. The plate was tapped at the side repeatedly before it was covered and kept at room temperature for 45 minutes and observed for haemagglutination. The 3 rd stage involved the addition of $25 \mu$ l of ND antibody serum to the well in the 2 nd stage, tapped at the side repeatedly before it was covered and kept at room temperature for 45 minutes and observed for haemagglutination inhibition. The pooled chicken blood sample which was ascertained to be free of ND antigen or any related antigen capable of cross-reaction, by expressing the 1st, $2 \mathrm{nd}$, and 3 rd reaction as stated in the procedure above was used to prepare the $1 \%$ chicken red blood cell suspension in PBS used for the HI test. 


\section{Haemagglutination test}

Haemagglutination test was carried out according to the method described by Grimes [13]. Twenty-five microlitre of PBS was dispensed into the each well in the first row of the microtitre plate. Twenty-five microlitre of the ND antigen suspension (La Sota vaccine) was then dispensed into the first well. A two-fold dilution of $25 \mu \mathrm{l}$ of the suspension was done across the wells up to the 11th well. Twenty-five microlitre of PBS solution was further added to each well in the first row. Then $25 \mu \mathrm{l}$ of $1 \%$ chicken RBC was dispensed into each of the wells. The 12 th well would serve as control, containing only PBS and red blood cells. The plate was tapped gently before it was covered and kept for 45 minutes at room temperature. The HA was determined by observing for a sharp button of RBCs (negative) or hazy film and no button of RBCs (positive) at the bottom of the plate. The end point was the last well to show complete haemagglutination and contained one haemagglutination unit (1 HAU). The cut-off titre was calculated using the range of initial dilutions from which $4 \mathrm{HAU}$ was arrived and this was used for the HI test.

\section{Haemagglutination inhibition test}

The sera collected from the chickens were tested for NDV specific antibody by the haemagglutination inhibition test (HI) as described by $\mathrm{H}$ os a i n et al. [15] and done according to the procedure of O I E [26]. The HI test was performed using the beta technique (constant virus and varying serum) against $4 \mathrm{HA}$ units of the virus computed from the HA titration. Two-fold serial dilution of $25 \mu \mathrm{l}$ serum was made with phosphate buffer saline (PBS) in U-bottomed microtitre plates up to 10th well in the 2nd row. Twenty-five microlitres of 4 haemagglutinating (HA) units of NDV virus or antigen (La Sota) was added up to the 11th well. The plates were kept at room temperature for 30 minutes to facilitate antigen-antibody reaction. Then $50 \mu \mathrm{l}$ of $1 \%(\mathrm{v} / \mathrm{v})$ chicken RBC suspension was added to each well. The 11th well contained antigen and RBCs as the positive control and the 12th well contained only RBCs as the negative control. After gentle mixing, the RBCs were allowed to settle at room temperature for 45 minutes and agglutination was assessed by tilting the plates. The samples showing peculiar central button shaped settling of RBCs were recorded as positive and maximum dilution of each sample causing haemagglutination inhibition was considered as the end point, which was used to estimate the HI titre. The HI titre of each serum sample was expressed as the reciprocal of the serum dilution.

\section{Data management and analyses}

The results obtained from the HI tests were subjected to descriptive statistics to determine the frequency and distribution of the ND antibody titre of Kaduna metropolis (Tables 2 and 3). Categorical values were evaluated using the Chi Square test to check for association; odds ratio at $95 \%$ confidence interval was used to measure the strength of association between variables and the prevalence of ND. All data obtained were analysed using SPSS statistical software (17.0)

Values of $\mathrm{P}<0.05$ were considered significant. Sample prevalence was estimated using the formula:

Sample Prevalence $=\frac{\text { Number of Positive Samples for ND Antibody }}{\text { Total Number of Samples Tested }} \times 100$

\section{RESULTS}

\section{Spatial distribution of Newcastle disease antibodies}

There were variations in the poultry distribution patterns between various communities. The poultry sampled were more concentrated in communities that had a cluster settlement pattern, while communities that had a linear settlement pattern had a low population of poultry. The antibody titre level of Newcastle disease was higher in communities that had entry points to the metropolis and houses that were closely situated with the live bird markets. The entry points included:

A. Zaria-Kaduna road;

B. Nnamdi Azikiwe bypass road;

C. Television garage;

D. Abuja Kaduna expressway and E. Kachia road (Fig. 1).

\section{Seroprevalence of ND antibodies}

The overall seroprevalence of Newcastle disease antibodies in the study area was $31.0 \%$ (124 out of 400). Among the positive Newcastle antibody sera, 103 out of $400(25.75 \%)$ had titres between $1 / 64$ and $1 / 512$ and 21 out of $400(5.25 \%)$ had titres $\geq 1 / 4096$ (Table 1$)$. The ND prevalence was $33.9 \%$ (39 out of 115), $31.8 \%$ (41 out 


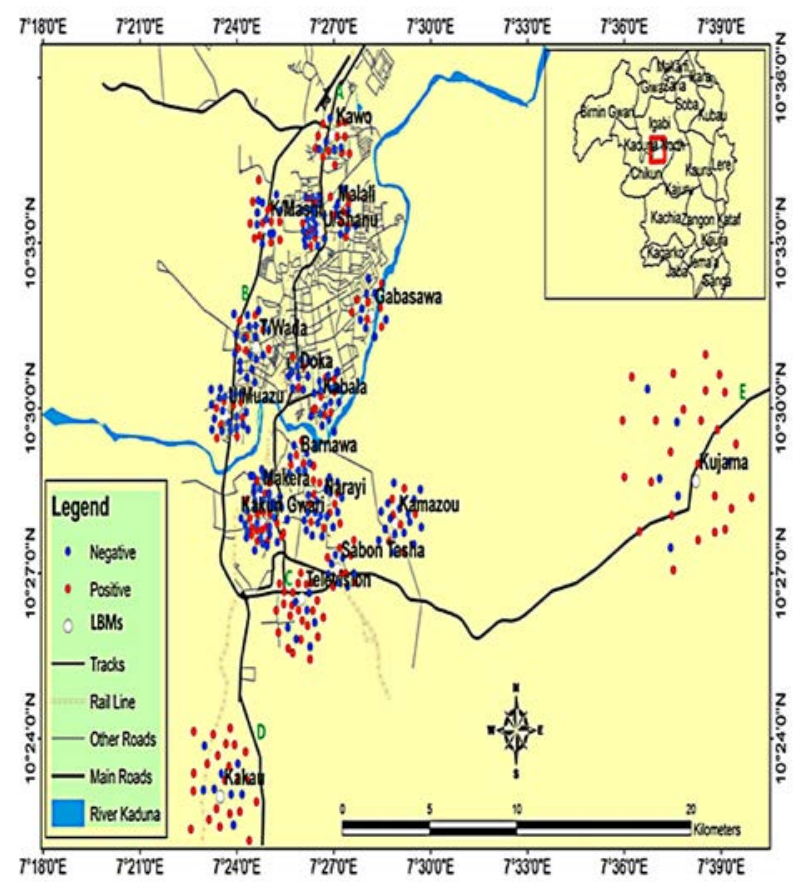

Fig. 1. Map of Kaduna Metropolis showing the coordinates of the positive and negative samples of Newcastle disease antibodies in districts where the study was carried out, Live bird markets (LBMs) and entry points A-E (ArcGIS 10.1)

of 129 ) and $28.2 \%$ (44 out of 156) for Kaduna North, Kaduna South and Chikun local governments, respectively (Table 2).

The prevalence of $29.8 \%$ (54 out of 181) was recorded in local chickens, while $32.0 \%$ (70 out of 219) was obtained from the exotic chickens, with local chickens having the odds ratio of 0.905 times likely of being positive for ND antibody than the exotic chickens (Table 3).

\section{DISCUSSION}

This serological study revealed the presence of circulating antibodies of NDV among chickens in three different districts of the Kaduna Metropolis. Also, the occurrence of detectable ND haemagglutinating (HI) antibodies in chickens tested in all of the three LGAs of Kaduna studied, with an overall seroprevalence of $31 \%$, was diagnostic evidence that ND was prevalent and likely enzootic in the study areas [17]. The antibodies detected were most likely due to natural infections in the local chickens rather than vaccination since local chickens were rarely vaccinated in

Table 1. Distribution of Newcastle disease antibody titre levels in the sera collected from chickens in the Kaduna metropolis of Kaduna State, Nigeria

\begin{tabular}{|c|c|c|c|c|c|c|c|c|c|c|c|c|c|}
\hline \multirow{2}{*}{$\begin{array}{l}\text { Local } \\
\text { government area }\end{array}$} & \multicolumn{13}{|c|}{ HI titre } \\
\hline & $\leq 1 / 2$ & $1 / 4$ & $1 / 8$ & $1 / 16$ & $1 / 32$ & $1 / 64$ & $1 / 128$ & $1 / 256$ & $1 / 512$ & $1 / 1,024$ & $1 / 2,048$ & $\geq 1 / 4,096$ & Total \\
\hline Kaduna North & 14 & 10 & 18 & 14 & 20 & 10 & 10 & 7 & 5 & 5 & 1 & 1 & 115 \\
\hline Kaduna South & 14 & 17 & 15 & 25 & 17 & 5 & 9 & 10 & 10 & 4 & 1 & 2 & 129 \\
\hline Chikun & 17 & 29 & 23 & 25 & 18 & 10 & 8 & 11 & 8 & 3 & 3 & 1 & 156 \\
\hline Total & 45 & 56 & 56 & 64 & 55 & 25 & 27 & 28 & 23 & 12 & 5 & 4 & 400 \\
\hline$\%$ & 11.25 & 14 & 14 & 16 & 13.75 & 6.25 & 6.75 & 7 & 5.75 & 3 & 1.25 & 1 & 100 \\
\hline
\end{tabular}


Table 2. Distribution of Newcastle disease titre levels in sera collected from chickens in the three Local Government Areas of the Kaduna metropolis of Kaduna State, Nigeria

\begin{tabular}{|c|c|c|c|c|}
\hline \multirow{2}{*}{$\begin{array}{l}\text { Local } \\
\text { Government Area }\end{array}$} & \multicolumn{2}{|c|}{ HI titre } & \multirow[b]{2}{*}{ Total } & \multirow[b]{2}{*}{$\%$} \\
\hline & $<1 / 64$ (-ve) & $\geq 1 / 64$ (+ve) & & \\
\hline Kaduna North & 76 & 39 & 115 & 33.9 \\
\hline Kaduna South & 88 & 41 & 129 & 31.8 \\
\hline Chikun & 112 & 44 & 156 & 28.2 \\
\hline Total & 276 & 124 & 400 & 31 \\
\hline
\end{tabular}

Chi square value $\left(X^{2}\right)=1.063 ;$ P-value = 0.588; (-ve) —Negative ND antibody sera; (+ve) —Positive antibody sera

Table 3. Seroprevalence of Newcastle disease in the breed of chickens in Kaduna metropolis of Kaduna State, Nigeria

\begin{tabular}{lccccc}
\hline \multicolumn{1}{c}{ Breed } & $\begin{array}{c}\text { No. of samples } \\
\text { tested }\end{array}$ & $\begin{array}{c}\text { No. of samples positive } \\
\text { for ND antibody }\end{array}$ & $\begin{array}{c}\text { No. of samples negative } \\
\text { for ND antibody }\end{array}$ & $\begin{array}{c}\text { Prevalence } \\
{[\%]}\end{array}$ & $\begin{array}{c}\text { Odds } \\
\text { Ratio }\end{array}$ \\
\hline Local chickens & 181 & 54 & 127 & 29.8 & 0.905 \\
Exotic chickens & 219 & 70 & 149 & 32.0 & 1.00 \\
\hline Total & $\mathbf{4 0 0}$ & $\mathbf{1 2 4}$ & $\mathbf{2 7 6}$ & $\mathbf{3 1 . 0}$ \\
\hline
\end{tabular}

$95 \% \mathrm{Cl}=$ Confidence Interval; Chi square value $\left(\chi^{2}\right)=0.210 ; \mathrm{P}$-value $=0.647$

Nigeria [1], while most likely due to vaccination in the exotic chicken flock [27].

Our study demonstrated a relatively comparable seroprevalence rate of ND in chickens obtained by other investigators in other countries, i. e., with an overall seroprevalence rate of $33 \%$ in Pakistan [20], and $27.86 \%$ in backyard and small-scale chicken poultry farms in Ethiopia [8].

However, our study revealed a relatively lower seroprevalence rate of ND compared to the overall seroprevalence rate of $66.5 \%$ in commercial poultry farms, village households and live bird markets in Benue State [1]; $63.5 \%$ in local and exotic chickens in the Gwagwalada [5]; $38.5 \%$ recorded in both Bauchi and Gombe States [22]; $79.6 \%$ in North Gondar zone of Ethiopia [9] and $40.13 \%$ reported in unvaccinated backyard poultry in Iran [30]. On the other hand, our study showed a higher seroprevalence rate as compared to the overall seroprevalence rate of $22.3 \%$ in cross-bred chickens in Afikpo [25], and $6.2 \%$ in the Barda region of Azerbaijan [34].

These observed differences in the seroprevalence of ND may be as a result of differences of ecological factors in NDV survival and transmission, and variations in sam- pling methods [31]. This could also be as a result of local preventive methods used against ND in the study area [6]. Although no advanced field and laboratory research was done in this study to differentiate ND antibodies due to vaccination from those from active infections.

Also, the titre of serum antibodies to ND virus in chickens could be affected if the chickens were infected with IBD virus, since it has been reported to be significantly lower than that of birds infected with ND virus alone [19]. It has also been reported that IBD virus affects ND virus excretion from chickens as ND virus was more frequently isolated from chickens infected with IBD virus, without the IBD virus infection altering the pathogenicity of ND virus in chickens [19].

\section{CONCLUSIONS}

The spatial distribution of ND from this study showed a higher concentration of ND antibodies at entry routes to the metropolis, signifying the importance of bird movement in the spread of the disease. The entry points include: 
A. Zaria-Kaduna road;

B. Nnamdi Azikiwe bypass road;

C. Television garage;

D. Abuja-Kaduna expressway and

E. Kachia road.

Serological study showed a $31 \%$ prevalence (124 out of 400) of ND antibodies in the study area indicating the enzootic nature of the disease. The ND prevalence was $33.9 \%$ (39 out of 115), $31.8 \%$ (41 out of 129) and $28.2 \%$ (44 out of 156) for Kaduna North, Kaduna South and Chikun local governments respectively. Newcastle disease prevalence of $29.8 \%$ (54 out of 181) was recorded in local chickens while $32.0 \%$ (70 out of 219) was obtained from the exotic chickens, with local chickens having the odds ratio of 0.905 times likely of being positive for ND antibody than exotic chickens.

\section{ACKNOWLEDGEMENT}

We would like to acknowledge the MacArthur Foundation Project for their immense support in providing the full financial support to this research.

\section{REFERENCES}

1. Abah, H. O., Ochola, P. F., Ishaya, V., 2020: Survey for Newcastle disease virus antibodies in local chickens, ducks and pigeons in Makurdi, Nigeria. Anim. Vet. Sci., 8, 3, 55-59 DOI: $10.11648 /$ j.avs.20200803.12.

2. Abdisa, T., Tagesu, T., 2017: Review on Newcastle disease of poultry and its public health importance. J. Vet. Sci. Technol., 8, 3, 441. DOI: 10.4172/2157-7579.1000441.

3. Abdullahi, J., Shaibu-Imodagbe, E. M., Mohammed, F., Sa'id, A., Dahiru, I. U., 2009: Rural-urban migration of the Nigerian work populace and climate change effects on food supply: A case study of Kaduna city in Northern Nigeria. In Fifth Urban Research Symposium: Cities and Climate Change: Responding to the Urgent Agenda, Marseille, France, June 28-30, 16 pp.

4. Aliyu, H. B., Sa'idu, L., Abdu, P. A., Oladele, S. B., 2015: Retrospective analysis of Newcastle disease diagnosed at the poultry clinic of Ahmadu Bello University, Zaria, Nigeria. Sok. J. Vet. Sci., 13, 3, 42-48. DOI: 10.4314/sokjvs.v13i3.7.

5. Ameh, J. A., Mailafia, S., Olatunde, H., Olabode, H. O., Adah, B. J., Okoh, G. J., et al., 2016: Sero-prevalence of
Newcastle disease virus antibodies in local and exotic chickens in Gwagwalada, Nigeria. J. Vet. Med. Anim. Health, 8, 11, 193-198. DOI: 10.5897/JVMAH2016.0482.

6. Anebo, Z. G., Teklemichael, K., Belachew, B., Tadios, Addisalem, H., 2014: Evaluation of the Newcastle disease antibody level after vaccination regimes in chickens in Debrezeit Agricultural Research Center, Ethiopia. J. Vet. Med. Anim. Health, 6, 1, 7-12. DOI: 10.5897/JVMAH2013.0229.

7. Anzaku, S. A., Umoh, J. U., Abdu, P. A., Kabir, J., Bala, A., 2017: Serological survey of Newcastle disease in free ranging local chickens in the Federal Capital Territory, Abuja, Nigeria. New J. Sci., 2017, 9646138, 1-5. DOI: 10.1155/ $2017 / 9646138$.

8. Asfaw Geresu, M., Elemo, K. K., Kassa, G. M., 2016: Newcastle disease: Seroprevalence and associated risk factors in backyard and small scale chicken producer farms in Agarfa and Sinana Districts of Bale Zone, Ethiopia. J. Vet. Med. Anim. Health, 8, 99-106. DOI: 10.5897/JVMAH2015.0427.

9. Birhan, M., Birhan, M. I., Tesfaye, S., Tariku, A., 2019: Detection of antibodies against Newcastle and infectious bursal disease on chicken in north Gondar zone, Ethiopia. Online J. Anim. Feed Res., 9, 2, 51-58.

10. Cattoli, G., Fusaro, A., Monne, I., Molia, S., Le-Menach, A., Maregeya, B., et al., 2010: Emergence of new genetic lineage of Newcastle disease virus in West and Central Africa-Implications for diagnosis and control. Vet. Microbiol., 142, 3-4, 168-176. DOI: 10.1016/j.vetmic.2009.09.063.

11. Gary, F., Diop, B., Barbosa, H., 2010: Performances of Veterinary Services (PVS) Gap Analysis Report: Federal Republic of Nigeria. World Organisation for Animal Health, Paris, France, 22-23.

12. Getabalew, M., Alemneh, T., Akeberegn, D., Getahun, D., Zewdie, D., 2019: Epidemiology, diagnosis and prevention of Newcastle disease in poultry. Am. J. Biomed. Sci. Res., 2019, 3, 1. AJBSR. MS.ID.000632. DOI: 10.34297/AJBSR.2019.03.000632.

13. Grimes, S. E., 2002: A Basic Laboratory Manual for the Smallscale Production and Testing of I-2 Newcastle Disease Vaccine. Food and Agricultural Organisation (FAO) Publication No. 22, Regional Office for Asia and the Pacific (RAP), Bangkok, Thailand, $136 \mathrm{pp}$.

14. Haile, B., Fentie, T., 2020: The role of live chicken markets as a source of replication and dissemination of Newcastle disease virus in chickens, northwest Ethiopia. Poult. Sci., 99, 11, 5415-5421. DOI: 10.1016/j.psj.2020.08.025.

15. Hossain, K. M., Ali, M. Y., Yamato, I., 2010: Antibody levels against Newcastle Disease Virus in chickens in Rajshahi and 
surrounding districts of Bangladesh. Int. J. Biol., 2, 2, 102106. DOI: 10.5539/ijb.v2n2p102.

16. Ibitoye, E. B., Jimoh, A. A., Mungadi, H. U., 2013: A retrospective (2007-2011) analysis of Newcastle disease diagnosed at Avian clinic of Veterinary Teaching Hospital, Usmanu Danfodiyo University Sokoto, Nigeria. Curr. Res. Poult. Sci., 3, 1, 12-17. DOI: 10.3923/crpsaj.2013.12.17.

17. Jibril, A. H., Umoh, J. U., Kabir J., Saidu, L., Magaji, A. A., Bello, M. B., et al., 2014: Newcastle disease in local chickens of live bird markets and households in Zamfara State, Nigeria. ISRN Epidemiology 2014, Article ID 513961. DOI: 10.1155/ 2014/513961.

18. Kapczynski, D. R., Afonso, C. L., Miller, P. J., 2013: Immune responses of poultry to Newcastle disease virus. Dev. Comp. Immunol., 41, 3, 447-453 DOI: 10.1016/j.dci.2013.04.012.

19. Kashif-ur-Rehman, Ahmad, M., Raza, M. A., Ahmad, M. J., Joiya, M. H., Imtiaz-ul-Haq, et al., 2014: Effects of infectious bursal disease vaccine on the immunity induced by Newcastle disease vaccine in broiler birds. Sci. Int. (Lahore), $26,1,243-247$.

20. Khan, M. Y., Arshad, M., Hussain, I., 2011: Epidemiology of Newcastle disease in rural poultry in Faisalabad, Pakistan. Int. J. Agric. Biol., 13, 491-497. DOI: 10-705/RNK/2011/134-491-497.

21. Lawal, J. R., El-Yuguda, A. D., Ibrahim, U. I., 2016: Survey on prevalence of Newcastle disease in village poultry at live bird markets in Gombe, Nigeria. J. Anim. Sci. Livest. Prod., 1, 1,2-9. DOI: 10.21767/2577-0594.100001.

22. Musa, I. W., Abdu, P. A., Sackey, A. K. B., Oladele, S. B., Lawal, S., Yakubu, I. U., 2010: Outbreak of velogenic viscerotropic Newcastle disease in broilers. Int. J. Poult. Sci., 9, 1116-1119. DOI: 10.3923/ijps.2010.1116.1119.

23. Musa, W. I., Abdu, P. A., Sa'idu, L., Bello, M., 2016: Survey for avian influenza and Newcastle disease antibodies and viruses in domestic and wild birds in Bauchi and Gombe States, Nigeria. In 17th International Congress on Infectious Diseases, Hyderabad, India, March 2-5/Int. J. Infect. Dis., 45S: 1-477 (472). DOI: 10.1016/j.ijid.2016.02.997.

24. National Population Commission (NPC), 2006: Social Statistic in Nigeria, National Bureau of Statistics: Federal Republic of Nigeria, 300 pp.

25. Nworie, O., Ezeifeka, G. O., Ogbu, O., Ogbu, M. A., Anyim, C., Ugwu, J. I., et al., 2012: Sero-prevalence of Newcastle disease in humans and apparently cross-breed of chickens in Nigeria. Cent. Eur. J. Exp. Biol., 1, 2, 69-73.
26. Office International des Epizooties (OIE), 2008: Manual of Diagnostic Tests and Vaccines for Terrestrial Animals. 6th edn., OIE, Paris, France, 1, 581-582.

27. Orsi, M. A., Doretto, Jr., L., Camillo, S. C. A., Reischak, D., Ribeiro, S. A. M., Ramazzoti, A., et al., 2010: Prevalence of Newcastle disease virus in broiler chickens (Gallus gallus) in Brazil. Braz. J. Microbiol., 41, 2, 349-357. DOI: 10.1590/ S1517-83822010000200014.

28. Perry, B. D., Randolph, T. F., Bett, B., Grace, D., Globig, A., Fadiga, M., et al., 2011: Independent Impact Assessment of the World Bank-funded Nigeria Avian Influenza Control and Human Pandemic Preparedness and Response Project (NAICP). Nigeria, 258 pp.

29. Rivas, A. L., Chowell, G., Schwager, S. J., Fasina, F. O., Hoogesteijn, A. L., Smith, S. D., et al., 2010: Lessons from Nigeria: The role of roads in the geo-temporal progression of avian influenza (H5N1) virus. Epidemiol. Infect., 138, 192198. DOI: 10.1017/S0950268809990495.

30. Saadat, Y., Ghafouri, S. A., Tehrani, F., Langeroudi, A. G., 2014: An active serological survey of antibodies to Newcastle disease and avian influenza (H9N2) viruses in the unvaccinated backyard poultry in Bushehr province, Iran, 20122013. Asian Pac. J. Trop. Biomed., 4 (Suppl. 1), S213-S216. DOI: 10.12980/apjtb.4.2014c1293.

31. Salihu, A. E., Chukwuedo, A. A., Echeonwu, G. O. N., Ibu, J. O., Chukwuekezie, J. O., Ndako, J., et al., 2012: Seroprevalence of Newcastle disease virus infection in rural household birds in Lafia, Akwanga and Keffi Metropolis, Nasarawa State Nigeria. Int. J. Agric. Sci., 2, 2, 109-112.

32. Shittu, I., Joannis, T. M., Georgina, N., Odaibo, O., Olufemi, D., 2016: Newcastle disease in Nigeria: Epizootiology and current knowledge of circulating genotypes. Virus Dis., 27, 4, 329-339. DOI 10.1007/s13337-016-0344-6.

33. Thrusfield, M. V., 2005: Veterinary Epidemiology, 3rd edn., Blackwell Science Limited, Oxford, UK, 233 pp.

34. Zeynalova, S., Guliyev, F., Vatani, M., Abbasov, B., 2015: Biosurveillance of avian influenza and Newcastle disease viruses in the Barda region of Azerbaijan using real time RTPCR and hemagglutination inhibition. Front. Microbiol., 6, 1128. DOI: $10.3389 /$ fmicb.2015.01128.

Received July 26, 2020

Accepted January 13, 2021 